\title{
Clinical competence of Guatemalan and Mexican physicians for family dysfunction management
}

\author{
Carlos Enrique Cabrera-Pivaral1,2, María de Jesús Orozco-Valerio², Alfredo Celis-de la Rosa²,
} María de los Ángeles Covarrubias-Bermúdez $z^{3}$ and Marco Antonio Zavala-González ${ }^{3}$

${ }^{1}$ Research Unit, Instituto Guatemalteco de Seguridad Social, Ciudad de Guatemala, Guatemala; ${ }^{2}$ Division of Disciplines for Development, Health Promotion y Preservation; ${ }^{3}$ Public Health Sciences Doctorate Program, Department of Public Health. University Center of Health Sciences, Universidad de Guadalajara, Guadalajara, Jal., Mexico

\begin{abstract}
Objective: To evaluate the clinical competence of Mexican and Guatemalan physicians to management the family dysfunction. Methods: Cross comparative study in four care units first in Guadalajara, Mexico, and four in Guatemala, Guatemala, based on a purposeful sampling, involving 117 and 100 physicians, respectively. Clinical competence evaluated by validated instrument integrated for 187 items. Non-parametric descriptive and inferential statistical analysis was performed. Results: The percentage of Mexican physicians with high clinical competence was $13.7 \%$, medium $53 \%$, low $24.8 \%$ and defined by random $8.5 \%$. For the Guatemalan physicians' $14 \%$ was high, average $63 \%$, and $23 \%$ defined by random. There were no statistically significant differences between healthcare country units, but between the medium of Mexicans (0.55) and Guatemalans (0.55) $(p=0.02)$. Conclusion: The proportion of the high clinical competency of Mexican physicians' was as Guatemalans.
\end{abstract}

KEY WORDS: Family health. Family practice. Physicians' family. Clinical competence.

\section{Introduction}

The family is considered to be a health indicator ${ }^{1}$ and a central point for individuals' comprehensive healthcare ${ }^{2}$. Specifically, managing family dysfunction is a strategy to approach health prtoblems ${ }^{3}$, since it is a risk factor for obesity in Mexican children ${ }^{4}$ and adults $^{5}$, it is related to poor nutritional status in Colombian geriatric subjects ${ }^{6}$ and inaccessibility of food to children, it is associated with suicide ideation and attempt in Colombian and Chilean adolescents ${ }^{8,9}$ and is one of the most important risk factors for suicide in the Latin American and Caribbean population ${ }^{10,11}$.

In this sense, clinical competence of physicians to prevent, diagnose and treat family dysfunctionality is highly important, and assessing it is therefore necessary $^{3}$. Some authors have shown that such competence is often low in the medical personnel; for example, in Cuba, the competence of 25 medical residents was assessed with regard to family care and only $11.8 \%$ approved more than $70 \%$ of the evaluation ${ }^{12}$. In Mexico, the competence of medical students of different grades was shown to be very low ${ }^{13}$, and another study that assessed the competence of 200 doctors showed that only $3 \%$ obtained a high score in the management of family dysfunction ${ }^{14}$.

The above-mentioned studies show significant knowledge, but, nevertheless, it is important for follow-up studies to be carried out, since physicians' clinical competence is an indirect indicator of the quality of care provided to the patient ${ }^{15}$. It is also important for this competence to be compared in different settings in order to identify common elements. Since Guatemala and Mexico have similar health systems ${ }^{16,17}$, and given that there is cooperation between colleagues

\section{Correspondence:}

María de los Ángeles Covarrubias-Bermúdez

Sierra Mojada, 950, Puerta 1, Edificio N, Planta Alta

Col. Lomas de Independencia

C.P. 44240, Guadalajara, Jal., México

E-mail: angelescovarrubias@ hotmail.com
Date of reception: 13-07-2016

Date of acceptance: 18-08-2016

DOI://dx.doi.org/10.24875/GMM.M18000056
Gac Med Mex. 2017;153:616-620

Contents available at PubMed www.gacetamedicademexico.com 
from both countries, the purpose of this study was to assess Mexican and Guatemalan physicians clinical competence for the management of family dysfunction.

\section{Method}

A cross-sectional, comparative study (Fig. 1) was carried out in four clinics of the city of Guadalajara, Jalisco, Mexico, and other four of the city of Guatemala, Guatemala, during the year of 2015. For the sample selection, a cluster-sampling was performed in four primary care units at each one of the cities, where 250 Guatemalan and 450 Mexican physicians were located. A sample of 117 doctors in Guadalajara and 100 in Guatemala was obtained by means of purposive sampling.
All physicians who accepted to participate in the study were included. Those working at emergency areas or night shifts were disregarded, and incompletely answered questionnaires were eliminated.

The study variable was the participants' clinical competence to manage family dysfunction, with the following indicators being considered: a) identification of risk factors, b) diagnostic integration, and c) identification of proposals and guidance.

To assess clinical competence, a previously-validated instrument was used ${ }^{14}$, which was composed of 187 items based on problematized clinical cases. Answer options were "true", "false" and "don't know", the values of which were 1 for correct answer, -1 for incorrect answer and 0 for "don't know". Maximum theoretical value was 187 points between all considered indicators. Additionally, academic and sociodemographic

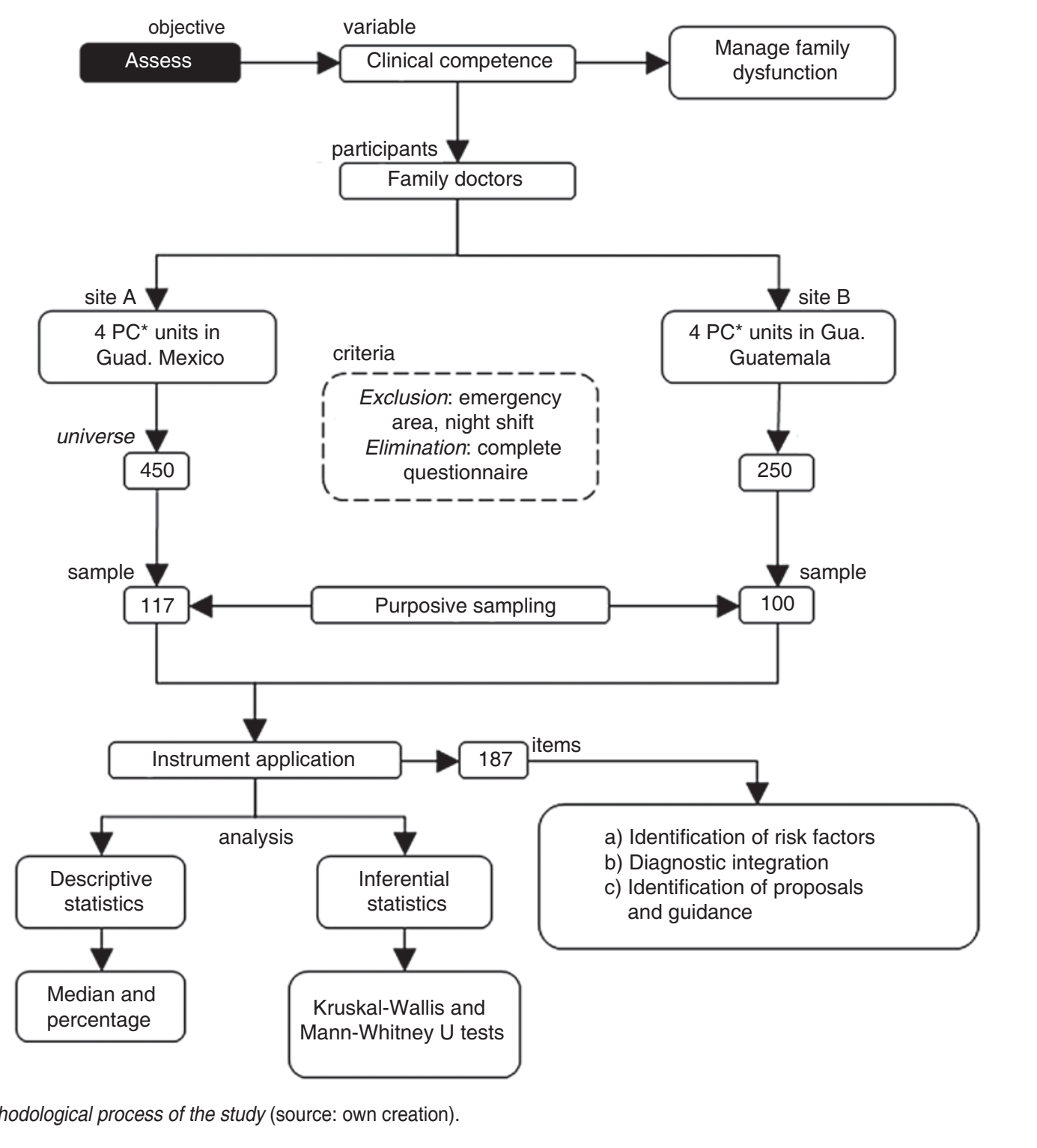

Figure 1. Methodological process of the study (source: own creation). 
variables were included in order to characterize the study group.

Based on observations referred by Viniegra et al. ${ }^{15}$, the following grades were considered for the measurement of clinical competence: a) randomly defined, $<60$ points, b) low level, 60-99, c) intermediate level, 100-149, and d) high level, $>140$, with a reliability of $90 \%$ according to the Kuder-Richardson test.

The assessment of the instrument was carried out by someone external to the study. Using descriptive statistics, frequencies and percentages were obtained with regard to participants' characteristics and level of competence. In addition, the competence difference between groups of the same country was obtained by comparing clinical competence level medians using the Kruskal-Wallis test and, finally, Mann-Whitney's U-test was used to compare overall median clinical competence of physicians according to the country of origin. The level of confidence for statistics was $95 \%$ $(p \leq 0.05)$, using Epi Info $^{\odot}$ version 7.1.5.2 for Windows ${ }^{\odot}$.

As part of the ethical considerations, the criteria established by the Regulations of the Health Statute in Matters of Research for Health ${ }^{18}$ and the Health Code of the Republic of Guatemala ${ }^{19}$ were taken into account, according to which, this study is considered to be free of risk, since the population was not intervened and, in addition, verbal consent was obtained from the participants and they were warranted anonymity.

\section{Results}

The characteristics of the study groups are shown in table 1.

The assessment of clinical competence to treat family dysfunction showed that $13.7 \%$ of Mexican and $14 \%$ of Guatemalan physicians obtained a high score; in the same order, 53 and $63 \%$ had intermediate level, 24.8 and $23 \%$, low level, and $8.5 \%$ had a randomly defined level only for Mexicans (Table 2).

When the Guadalajara medical units were compared, no statistically significant differences were found with regard to their level of clinical competence, with the same being observed in the Guatemalan clinics (Table 3).

The comparison between overall medians of each sample revealed a statistically significant difference (Table 3). The median for the Guadalajara group was higher than that for Guatemala ( $p>0.05)$.
Table 1. Physicians' demographic, academic and working characteristics

\begin{tabular}{|c|c|c|c|c|c|}
\hline \multirow[t]{2}{*}{ Variables } & \multicolumn{2}{|c|}{$\begin{array}{c}\text { Guadalajara } \\
(\mathrm{N}=117)\end{array}$} & \multicolumn{3}{|c|}{$\begin{array}{l}\text { Guatemala } \\
(N=100)\end{array}$} \\
\hline & $f$ & $\%$ & $f$ & $\frac{1}{2}$ & $\%$ \\
\hline \multicolumn{6}{|l|}{ Gender } \\
\hline Male & 47 & 40.2 & 52 & ह & 52.0 \\
\hline Female & 70 & 59.8 & 48 & ¿ & 48.0 \\
\hline \multicolumn{6}{|c|}{ Employment contract } \\
\hline Permanent & 98 & 83.8 & 56 & & 56.0 \\
\hline Temporary & 19 & 16.2 & 44 & $\ddot{\omega}$ & 44.0 \\
\hline \multicolumn{6}{|c|}{ Seniority in the job (years) } \\
\hline$<10$ & 19 & 16.2 & 42 & $\overline{\mathrm{o}}$ & 42.0 \\
\hline $10-19$ & 56 & 47.9 & 24 & 을 & 24.0 \\
\hline$>20$ & 42 & 35.9 & 34 & $\stackrel{\oplus}{\epsilon}$ & 34.0 \\
\hline \multicolumn{6}{|c|}{ Experience (years) } \\
\hline$<10$ & 33 & 28.2 & 56 & $\frac{\varsigma}{\circ}$ & 56.0 \\
\hline $10-19$ & 42 & 35.9 & 32 & $\bar{n}$ & 32.0 \\
\hline$>20$ & 42 & 35.9 & 12 & $\underline{E}$ & 12.0 \\
\hline \multicolumn{6}{|l|}{ Shift } \\
\hline Morning & 61 & 52.1 & 68 & $\frac{c}{9}$ & 68.0 \\
\hline Afternoon & 56 & 47.9 & 32 & $\stackrel{ \pm}{ \pm}$ & 32.0 \\
\hline
\end{tabular}

Source: own creation.

Table 2. Physicians' level of competence by strata

\begin{tabular}{|c|c|c|c|c|c|}
\hline \multirow{2}{*}{$\begin{array}{l}\text { Level of } \\
\text { competence }\end{array}$} & \multirow[t]{2}{*}{ Scoring range } & \multicolumn{2}{|c|}{ Guadalajara } & \multicolumn{2}{|c|}{ Guatemala } \\
\hline & & $f$ & $\%$ & $f$ & $\%$ \\
\hline Randomly defined & $<8$ & 10 & 8.5 & & 0.0 \\
\hline Low & $9-16$ & 29 & 24.8 & 23 & 23.0 \\
\hline Intermediate & $17-24$ & 62 & 53.0 & 630 & 63.0 \\
\hline High & 25 & 16 & 13.7 & $14 \frac{\mathrm{c}}{\mathrm{O}}$ & 14.0 \\
\hline Total & & 117 & 100.0 & $100^{\circ}$ & 100.0 \\
\hline
\end{tabular}

Source: instrument applied to primary care family doctors from Guadalajara and Guatemala.

Table 3. Physicians' level of competence by medical unit and city

\begin{tabular}{|c|c|c|c|c|c|c|c|}
\hline \multirow[t]{2}{*}{ Medical unit } & \multicolumn{3}{|c|}{ Guadalajara } & \multicolumn{3}{|c|}{ Guatemala } & \multirow[t]{2}{*}{$\mathbf{p}^{\dagger}$} \\
\hline & $\mathbf{N}$ & Median & Interval & $\mathrm{n}$ & Median & Interval & \\
\hline A & 30 & 19 & $6-24$ & 21 & 15 & $4-19$ & 0.02 \\
\hline B & 27 & 15 & $12-26$ & 24 & 12 & $8-2 \overline{1}$ & 0.01 \\
\hline C & 29 & 18 & $8-25$ & 26 & 14 & $6-19$ & 0.04 \\
\hline D & 31 & 17 & $12-27$ & 29 & 12 & $9-21$ & 0.01 \\
\hline Total & 117 & 15 & $6-27$ & 100 & 12 & $4-21$ & 0.02 \\
\hline$p^{*}$ & 0.55 & & & 0.55 & & 욱 & - \\
\hline
\end{tabular}

Source: own creation.

*According to Kruskal-Wallis test.

†According to Mann-Whitney's U-test. 


\section{Discussion}

This study represents a current measurement of Mexican physicians' clinical competence to manage family dysfunction. In the case of Guatemala, it provides new knowledge, since this subject had not been explored in this country.

Though similar, the results are not comparable to those of other existing studies ${ }^{12,13}$, since the indicators, methods and participants considered by the authors are different. However, they are comparable to those presented by Cabrera-Pivaral et al. ${ }^{14}$, with their study showing that Mexican physicians' level of clinical competence increased by $10.3 \%$ over the last 9 years. It is possible for this result to be due to the Health Sectorial Plan implementation ${ }^{20}$, which emphasizes on the need to address health in consonance with gender, culture and lifestyles, where working with the family is essential.

On the other hand, although Mexicans showed a significant advantage over Guatemalans regarding high clinical competence, the level of competence was insufficient in both contexts, since 86.3 and $86 \%$, respectively, obtained scores that placed them at intermediate, low and randomly defined levels. This result may be due to the lack of educational programs directed to primary care and interdisciplinary work, as well as to the reduced number of universities certifying the quality of their services ${ }^{21}$.

In the specific case of Guatemala, national reports show that the health system is maintained within a biomedical care model, since social workers and psychologists act only on a complementary basis, which is a situation that makes it difficult for the physician to provide care to patients from the family point of view $^{22}$. Similarly, although primary care is imperative, health actions are mostly for diagnosis, treatment and rehabilitation ${ }^{23}$, and the care of family dysfunction is therefore often set aside.

New studies that include organizational and working environment variables need to be carried out in order to explain the differences between the levels of competence of the groups considered in this study.

As for representativeness of the sample, it is deemed to be adequate, since clinical competence was evaluated in a number of participants that exceeded the minimal required for a descriptive study of qualitative variables in finite universes, $n=\left(N Z^{\wedge} 2 \mathrm{pq}\right) / \mathrm{d}^{\wedge} 2(\mathrm{~N}-1)$ $+Z^{\wedge} 2 \mathrm{pq}$ ), considering, for example, in the universe of the Mexican context of $\mathrm{N}=450$, a $\mathrm{p}$-value $=0.88$ $(q=0.12)$, with this being based on a prevalence of intermediate to randomly-defined clinical competence level of $88 \%$ in Mexican physicians ${ }^{14}$.

However, as a limitation of the study, the construction of the sample by means of purposive sampling is considered to likely have generated a sampling bias, since physicians' motivation to participate could have been a self-perception of a high level of command on the subject, in which case the results would be overestimated.

Nevertheless, the heterogeneity of results was able to show that assessing physicians' clinical competence to manage family dysfunction is necessary, since it is an indicator of problems in physicians' practice that hinder medical care according to the standards set forth by the Mexican and Guatemalan governments, which are intended to to establish action strategies based on family and community needs ${ }^{20,24}$.

\section{References}

1. Organización Mundial de la Salud. Índices estadísticos de la salud de la familia. Washington, D.C.: Organización Mundial de la Salud; 1976. (Consultado el 1 de junio de 2016.)Disponible en: http://apps.who.int/iris/ bitstream/10665/40938/1/WHO_TRS_587_spa.pdf.

2. Herrera Santí, PM. La familia funcional y disfuncional, un indicador de salud. Rev Cubana Med Gen Intergr. 1997:13(6):591-9. Disponible en: http://scielo.sld.cu/scielo.php?script=sci_arttext\&pid=S0864-21251997000600013\&lng=es.

3. Garza-Elizondo T. Dimensiones de la funcionalidad familiar a evaluar en la entrevista familiar. En: Trabajo con familias: abordaje médico e integral. 3. ${ }^{a}$ ed. México: Garza \& Gutiérrez; 2015. 97-104.

4. González-Rico JL, Vásquez-Garibay EM, Cabrera-Pivaral CE, et al. La disfunción familiar como factor de riesgo para obesidad en escolares mexicanos. Rev Med Inst Mex Seguro Soc. 2012;50:127-34.

5. Jaramillo-Sánchez R. Disminución de peso y funcionalidad familiar en sujetos con obesidad y sobrepeso. Rev Med Inst Mex Seguro Soc. 2012;50:487-92.

6. Carrazco-Peña KB, Tene CE, Elizalde AM. Disfunción familiar y desnutrición en el anciano. Rev Med Inst Mex Seguro Soc. 2015;53:14-9.

7. Taborda-Restrepo PA, Pérez-Cano ME. Funcionalidad familiar, seguridad alimentaria y estado nutricional del programa departamental de complementación alimentaria de Antioquia. CES Medicina. 2011;25:6-19.

8. Von-Dessauer B, Ortiz P, Hinostroza T, et al. Intento de suicidio vía ingesta de fármacos en niños. RevChilPediatr.2011;82:42-8.

9. Álvarez-Latorre JM, Cañón-Castrillón JJ, Bernier-Ocampo LH, et al. Factor de riesgo suicida y factores asociados en adolescentes de una institución educativa de Palestina-Caldas. Arch Med. 2012;13:127-41.

10. Cañón-Buitrago SC. Factores de riesgo asociados a conductas suicidas en niños y adolescentes. Arch Med. 2011;11:62-7.

11. Teti G, Rebok F, Rojas SM, et al. Systematic review of risk factors for suicide and suicide attempt among psychiatric patients in Latin America and Caribbean. Rev Panam Salud Públ. 2014;36:124-33.

12. Rocha-Vázquez M, San Juan-Bosh MA. Evaluación de la competencia profesional de residentes de Medicina General Integral para la atención a la familia. Educ Med. 2010;13:41-6.

13. Dorado-Gaspar MP, Loría-Castellanos J, Guerrero-Martínez MB. Aptitud clínica hacia el estudio integral de la familia en residentes de medicina familiar. Arch Med Fam. 2006;3:169-74.

14. Cabrera-Pivaral CE, Rodríguez-Pérez I, González-Pérez G, et al. Aptitud clínica de los médicos familiares en la identificación de la disfunción familiar, en unidades de medicina familiar de Guadalajara, México. Salud Mental. 2006;29:40-6.

15. Viniegra L, Jiménez JL, Pérez Padilla JR. El desafío de la evaluación de la competencia clínica. Rev Invest Clin. 1991;43:87-95.

16. Gómez O, Sesma S, Becerril V, et al. Sistema de salud de México. Salud Publica Mex.2011;53:220-32.

17. Becerril-Montekio V, López-Dávila L. Sistema de salud de Guatemala. Salud Publica Mex.2011;53(Supl2):197-208.

18. Reglamento de la Ley general de salud en materia de investigación para la salud. México D.F.: Diario Oficial de la Federación de los Estados Unidos Mexicanos; 1986. 
19. Código de salud. Decreto número 90-97. Ciudad de Guatemala: Diario Oficial de la Federación de la República de Guatemala; 1997.

20. Gobierno de la República. Programa Sectorial de Salud 2013-2018. México, D.F.: Diario Oficial de la Federación; 2013.

21. Organización Panamericana de la Salud. La renovación de la atención primaria de salud en las Américas. La formación en medicina orientada hacia la atención primaria de salud. Washington D.C.: Organización Panamericana de la Salud; 2008. (Consultado el 1 de junio de 2016.) Disponible en: http://www.nodo50.org/fadsp/archivos/APS-Formacion_ Medicina_Orientada_APS\%5B1\%5D.pdf.

22. Avila C, Bright R, Gutiérrez JC, et al.Análisis del Sistema de Salud 2015 Guatemala: Proyecto Health Finance and Governance. Abt Associates; 2015. (Consultado el 1 de junio de 2016.)Disponible en: https://www.
usaid.gov/sites/default/files/documents/1862/Guatemala-Analisis-del-Sector-Publico-Salud-Esp-INFORME-COMPLETO-FINALAbr2016.pdf.

23. Estrada-Galindo G. El sistema de salud en Guatemala.Guatemala: Naciones Unidas; 2008. (Consultado el 1 de junio de 2016.)Disponible en:https://idl-bnc-idrc.dspacedirect.org/bitstream/handle/10625/36342/127653.pdf?sequence=1\&isAllowed=y.

24. Ministerio de Salud Pública y Asistencia Social. Diagnóstico Nacional de Salud. Guatemala: Ministerio de Salud Pública y Asistencia Social; 2012. (Consultado el 1 de junio de 2016.)Disponible en: http://www.mspas.gob. gt/images/files/cuentasnacionales/publicaciones/11MSPAS(2012)Salud-marzo.pdf. 